\title{
Óvodás gyermekek csoportszobai térhasználatának vizsgálata a térszintaxis módszerével
}

\section{Keszei BARBARA - Böddi Zsófia - Dúll ANdrea}

ELTE Eötvös Loránd Tudományegyetem, Pedagógiai és Pszichológiai Kar, Pszichológiai Intézet; Pszichológiai Doktori Iskola; Budapesti Gazdasági Főiskola, Kereskedelmi, Vendéglátóipari és Idegenforgalmi Kar, Pedagógia Tanszék - Eötvös Loránd Tudományegyetem, Tanító- és Óvóképző Kar - ELTE Eötvös Loránd Tudományegyetem, Pedagógiai és Pszichológiai Kar, Pszichológiai Intézet; Budapesti Műszaki és Gazdaságtudományi Egyetem, Gazdaság- és Társadalomtudományi Kar, Szociológia és Kommunikáció Tanszék

Az óvodai csoportszobák vizsgálata kiemelt jelentőségü a koragyermekkori kutatások világában. Az óvoda mintát kínálhat, megannyi más mellett, a szociofizikai térrel való hatékony kapcsolat, a szociofizikai téri kompetencia kialakitásához. Ezért rendkívül fontos olyan óvodai környezetek kialakitása, melyek ezt az érzést biztositják az óvodásoknak. Jelen kutatásunkban az épitészek által használt térszintaxis módszer használatával, környezetpszichológiai szemléletben vizsgáljuk a csoportszobai környezetet, ill. a gyermekek és az óvodapedagógus térhasználatát. Feltáró kutatásunk célja jobban megérteni az óvodások és a pedagógusok térhasználati szokásait. Kutatásunkban óvodai csoportszobákban végzett természetes megfigyelések eredményeit mutatjuk be. Eredményeink alapján elmondható, hogy az óvodapedagógusok és a gyerekek egyaránt a fizikailag nehezebben elérhetö térrészeken töltöttek több idöt. A gyerekek térhasználatát a láthatóság jósolta be leginkább, vagyis ők olyan térrészeket választanak, melyek jól láthatóak a csoportszoba legtöbb pontjából. Véleményünk szerint az óvodai csoportszoba környezetpszichológiai elemzése térszintaktikai megközelitésben az óvodapedagógusok és a tervezök számára egyaránt hasznos lehet a környezetek kialakitásakor.

Kulcsszavak: térszintaxis, természetes megfigyelés, óvoda, szociofizikai térhasználat

\section{Bevezető}

A fizikai környezet szerepe régen megjelent a pedagógiai gondolkodásban. A környezet tanulásban való felhasználását már Comenius is említi (Földy, 1994). Ugyanakkor a fizikai környezet viselkedésre, gondolkodásra és érzelmeinkre való hatását szisztematikusan a 60-as évek óta a környezetpszichológia vizsgálja, amely a társas és a fizikai környezetet kölcsönkapcsolatban, szociofizikai környezetként elemzi (Dúll, 2009).

A fizikai környezettel folyamatos tranzakcióban állunk. A környezet és a személy kölcsönös egymásra hatása, interakciója állandó és egymástól elválaszthatatlan (DuránNarucki, 2008). A gyermekek nevelése és oktatása szempontjából ez azért kiemelt jelentőségü, mert a gyermekek többek között a bölcsődei, óvodai, iskolai környezettel való interakciók során szereznek tapasztalatokat önmagukról, képességeikről, tulajdonságaikról (Piaget és Inhelder, 1999, Ljubetić; 2012).

A kisgyermekkori bölcsődei és óvodai környezet befolyásolja a gyermekek viselkedését, játékának sajátosságát. A szociális környezeten túl a gyermek érzelmeire hatással vannak a fizikai környezet elemei, azok sajátosságai (pl. mennyiség, méret, szín) is (Pálfi, é.n., Dúll, 2015).

Az óvodai csoportszobákban zajló tevékenységek vizsgálata kiemelten fontos, hiszen ezek az ismeretek segíthetnek olyan környezeteket kialakítani, melyek használata hozzásegíti a gyermekeket az egészséges fejlődéshez. Jelen tanulmányunkban az építészek és a környezetpszichológusok által gyakran használt térszintaxis elméleti keretében és módszerével értelmezzük az óvodai csoportszobai térhasználatot, és rávilágítunk arra, hogy ez a megközelítés hogyan segítheti az óvodapedagógusok munkáját. 


\section{A csoportszoba mint tér}

Az Óvodai nevelés országos alapprogramja (2012) az óvoda személyi feltételei mellett a tárgyi feltételeiről is ír: „Az óvodának rendelkeznie kell a pedagógiai program megvalósitásához szükséges tárgyi feltételekkel. Az óvoda épületét, udvarát, kertjét, berendezését oly módon kell kialakítani, hogy az szolgálja a gyermekek biztonságát, kényelmét, megfeleljen változó testméretének, biztosítsa egészségük megőrzését, fejlődését. Tegye lehetővé mozgás- és játékigényük kielégitését, és a gyermekeket harmóniát árasztó színekkel, formákkal, anyagokkal vegye körül. A gyermekek által használt tárgyi felszereléseket számukra hozzáférhető módon és a biztonságukra figyelemmel kell elhelyezni. Az óvoda egyidejűleg biztosítson megfelelő munkakörnyezetet az óvodai munkatársaknak, teremtsen lehetőséget a szülők fogadására." (363/2012. (XII. 17.) Korm. rendelet az Óvodai nevelés országos alapprogramjáról)

A koragyermekkori intézményes környezetbe (bölcsőde, óvoda) kerülés stresszt jelent a gyermekek számára, kihívásokhoz kell alkalmazkodniuk. Háromféle szociofizikai stresszforrásról beszélhetünk ebben az esetben. Egyrészt a bölcsőde, óvoda új környezetet jelent, az otthoni környezet egyfajta elvesztésével (helyveszteség) jár. Másrészt az intézményben stresszforrást, kihívást jelent a személyes tér, magánszféra szabályozása a gyermek számára, sőt óvodáskorban jelenik meg markánsan a territoriális viselkedés is. Harmadrészt pedig a csoportszobai környezet a gyermekek számára zsúfoltság élményt nyújthat, amely stresszor az ember számára, legyen gyermek vagy felnőtt (Dúll, 2015).

A csoportszoba szociofizikai jellemzői befolyásolják a gyermekek érzelmeit, viselkedését. Természetesen a gyermekek egyénileg reagálnak mindezekre (pl. preferenciáik, korábbi tapasztalataik, „történetük” alapján) (Hegyi, é.n.), ám vannak olyan fizikai jellemzők, amelyekből általánosságban kiindulhatunk.

A pedagógus jó, ha tudatos a csoportszobában megtalálható színek, azok dominanciája terén (l. alább) és akár változtathat is. A tárgyak alakját tekintve a gyermekek a lekerekített, gömbölyủ formákat preferálják A méretek és a súly szempontjából is fontos átgondolni a berendezést, illetve a játékeszközöket (például ne legyenek túl nagy, nehéz, a gyermek számára nem uralható játékszerek, eszközök a csoportban). Hasonlóan tudatosan kell eljárni a tárgyak anyaga terén is, hiszen a taktilis információszerzés óvodáskorban (is) kiemelt jelentőségủ. Végül a csoportszobák berendezésénél - a tárgyak praktikussága mellett - lényeges szempont a tárgyak mennyisége. Hiszen a zsúfoltság érzését nem csak a gyermek környezetében lévő túl sok személy, hanem túl sok tárgy is keltheti (Hegyi, é.n.).

Ata, Deniz és Akman (2012) áttekintő tanulmányukban az óvodai csoportszoba fizikai környezete kapcsán négy faktort elemeznek: a tér, a zaj, a levegő jellemzői, illetve a színek és a megvilágítás. A tér sajátosságaival kapcsolatban összegzik, hogy a csoportszoba tevékenységei a meghatározóak, biztonságosnak és a világ felfedezésére alkalmasnak kell lennie. „A gyermekeknek olyan térre van szükségük, ahol tudnak másokkal játszani, ugyanakkor olyan csendes helyekre is, ahol a magányos tevékenységeiket folytathatják, felkínálva a lehetőséget az autonómiájuk és függetlenségük megélésére, emellett szükségük van egy biztonságos bázisra, ahová visszatérhetnek és visszavonulhatnak, amikor szükséges." (Ata, Deniz és Akman, 2012. 2035. o.)

A zaj tekintetében külső (behallatszó, például forgalom) és belső zajról beszélnek. A zaj csökkentése kapcsán felhívják a figyelmet az épület elhelyezkedése, a megfelelő gyermekfelnőtt arányra, illetve az épület tudatos tervezésére (adott tevékenységek - megfelelő helyiségben, térrészben). A levegő kapcsán kijelenthető, hogy a minősége a csoportszobában is kiemelten fontos, nemcsak az udvaron (Anderson és Bogdan, 2007, idézi Ata, Deniz és Akman, 2012). A levegő minősége, a szellőzés és a fütés összefüggésben van a gyermekek kognitív teljesítményével (Earthman, 2004, idézi Ata, Deniz és Akman, 2012) és a zajjal (Dockrell és Shield, 2004, idézi Ata, Deniz és Akman, 2012). Továbbá fontos ne- 
Óvodás gyermekek csoportszobai térhasználatának vizsgálata a térszintaxis módszerével

gatív tényező a levegő szennyezettsége (pl. a használt anyagok, eszközök miatt) a csoportszobában. A szerzők végül a csoportszobában használt színek és a megvilágítás hatását vizsgálják. A színek kétségkívül hatással vannak a gyermekek viselkedésére, hangulatára, ám a csoportszobában használt színek és az érzelmek kapcsolata még nem teljesen tisztázott. Ugyanakkor felhívják a figyelmet, hogy színekkel befolyásolhatjuk a tanulási tevékenységet is. A megvilágítás egyértelműen kulcsfontosságú tényező. Meghatározza a vizuális környezetet, amely összefügg a tapasztalatszerzési környezet esztétikai és pszichológiai jellemzőivel (Phillips,1997, idézi Ata, Deniz és Akman, 2012).

Az óvodában a felnőtt által irányított, ill. egyéb tevékenységek mellett a játék túlsúlyát kell hangsúlyoznunk, így az óvodai csoportszobától elvárható, hogy „játékorientált” (Pál$f i$, é.n.) legyen, azaz igazodjon a gyermekek szükségleteihez, ezen belüli is hangsúlyosan a játékhoz, játszáshoz (Stöckert, 2011). Továbbá nem feledkezhetünk meg a csoportszobai (játék)környezet nevelési szerepéről sem, mint például, hogy együttmúködésre vagy versengésre sarkall-e (Pálfi, é.n.).

Bár - érthető okokból - az óvodai csoportszoba a felnőtt számára áttekinthető, beláthatónak kell lennie, törekedni kell rá, hogy megteremtődjön a játékhoz szükséges légkör, a gyermekek igényei (például a „kuckósítás”) kielégüljenek. Továbbá célszerü, ha a csoportszoba egyes elemei könnyen variálhatók igény szerint (pl. könnyen mozdítható kisebb bútorok) (Stöckert, 2011).

Kovács és Bakosi (2005) három olyan szempontot összegez, amelyet a pedagógusok szem előtt tartanak a játékkörnyezet megteremtésekor: a játékfejlődés eltérő szempontjai, hely- és eszközigény; egyes játékoknak állandó helye szokott lenni amiatt, mert népszerüek vagy gyakoriak; illetve ki szoktak jelölni állandó játszóhelyeket a konfliktusok elkerülése céljából is (Kovács és Bakosi, 2011).

Az egyes óvodapedagógusok-óvodapedagógus párok, és így az óvodai csoportok is eltérnek a játszásra vonatkozó szokás-/szabályrendszerben. Míg egyes pedagógusok jobban ragaszkodnak ahhoz, hogy „bizonyos játékokkal csak bizonyos helyeken szabad játszani", mások ebben rugalmasabbak. Ugyanígy abban is eltérő a pedagógusok véleménye, hogy milyen mértékben engedik az elbújást (például asztalok alá), mennyire engedik a játékterek átvariálását a gyermekeknek. Azt is tudjuk, hogy vannak esetek, amikor a felnőtt ugyan átgondolja a pedagógiai tereket, játéktereket, ám a játék „varázslatában” a gyerekek átlépik (átlépnék) azokat (például piknikezni mennének a konstruáló szőnyegre).

Ugyanígy eltér a pedagógusok hozzáállása a "rendetlenség” fogalmával kapcsolatban is, vagyis hogy vajon mit tekintenek a pedagógusok már a játékszerek, játékterek rendetlenségének, és mikor avatkoznak be a tér használatába. A rendetlenség kapcsán vannak egyértelmű helyzetek, pl. a túl sok, zavaró, zsúfoltságot idéző, éppen nem használatban lévő játékszer, a későbbi helyrerakást is megnehezítő szituáció, de megfontolandó az is, hogy nem biztos, hogy minden rendetlenség, amit a felnőtt elsőre annak lát, hiszen a gyermeki játék sajátossága lehet a „rend a rendetlenségben" (Polcz, 1987). Sőt a rendetlenség folytonos monitorozása a felnőtt részéről gyakran épp nem támogatja a gyermekek játékát, hanem „játékrontó” viselkedéshez vezethet (Stöckert, 2011).

Természetesen a csoportszobai térhasználattól nehéz elvonatkoztatni a csoportszobában uralkodó szokás-/szabályrendszert, amelynek bizonyos aspektusai a térhasználatra is vonatkoznak. A társas érintkezés, a játszás szabályai kihatnak a térhasználati szokásokra is, ugyanakkor a térhasználatot a kevéssé tudatosuló, az elrendezésből fakadó tényezők is befolyásolhatják (Dúll, 2009).

Mindezek mellett természetesen a térhasználathoz érzelmi élmény is kapcsolódik. A gyakran használt helyekhez helykötődés érzése is kialakul, különösképpen, ha ezeken a helyeken hatékonynak érezzük magunkat (Dúll, 2007, 2009).

Összességében elmondhatjuk, hogy a környezet fizikai elemeinek éppúgy fontos szerepe van a gyermekek viselkedésében, érzelmeiben, mint a szociális komponenseknek, még 
akkor is, ha nem vagy kevésbé tudatosulnak (pl. Dúll, 2015). Az óvodai csoportszoba esetében is elmondható, hogy „a környezet minden pillanatban több információt tartalmaz, mint amennyit - különösen tudatosan - kezelni tudunk" (Dúll, 2015. 266. o.).

\section{A térhasználat megfigyelése}

Amennyiben a fizikai környezet hatásait kívánjuk vizsgálni, akkor először is abba a módszertani nehézségbe ütközünk, hogy - mint fentebb említettük - a fizikai környezet észlelésének folyamatai nem tudatosuló természetúek. Így a teret használó emberektől, a térhasználóktól nehéz információt nyerni a térhasználati szokásaikról, illetve az azokat meghatározó, befolyásoló tényezőkről, hiszen azok szinte csak akkor tudatosulnak, ha valamilyen szélsőséges, kiugró vagy kifejezetten kellemetlen, kényelmetlen helyzetben vannak jelen (például nem ér le a székről a gyerekek lába). Egy mindennapi szinten használt környezet jellegzetességeit, adott esetben "hibáit” gyakran nem vesszük észre (Dúll, 2009). Nyilván különösen nehéz a környezeti történesek észrevétele és megfogalmazása a gyerekek számára.

Ezt a nehézséget a kutatásokban például a megfigyelés módszerének használatával oldhatjuk fel. Természetesen a megfigyelés sem adhat választ minden kérdésre a térhasználat okaira vonatkozóan, viszont pontos, torzítások nélküli információt szolgáltat magáról a megfigyelt jelenségről.

Amennyiben pedig az óvodás korcsoportot vizsgáljuk, akkor a megfigyelés a preferált és gyakran használt módszerek körébe lép. Egy megfigyelés során a verbalitás kihagyásával az interpretációs problémák széles köre elkerülhető. Ez az a módszer, ami az óvodás korosztály életkori sajátosságainak is a leginkább megfelel, amennyiben objektív információkhoz szeretnénk jutni a gyermekekről (Böddi, Keszei, Serfózö és Dúll, 2015; Keszei, Böddi és Dúll, 2016; Böddi, 2017). Azokban a kutatásokban, melyekben nem a tér használatára irányuló metakognícióra (vö. pl. Csíkos, 2007) vagyunk kíváncsiak, hanem a vizsgált térben való viselkedésre, térhasználatra a megfigyelés módszere a legjobb választás.

\section{A térszintaxis}

A szintaxis (azaz a mondattan) a nyelvészetben a szavak szószerkezetekké és mondatokká összekapcsolódásának szabályait írja le. „A térszintaxis a térkapcsolatok analízise úgy, hogy az elemzés egységeinek (pl. helyiségek) azonosítása után felmérik, hogy az egyes terek közvetlenül vagy közvetve kapcsolódnak-e egymáshoz. A kapcsolat szintaktikailag közvetlen, felszínes, ha kisszámú egymást keresztező téren kell áthaladni az egyik helyről a célhely eléréséhez. A kapcsolat közvetett vagy szintaktikailag mély, ha nagyszámú közbeiktatott tér van a két egység között. Egy tér integrált, ha minden más térrel felszínes kapcsolata van az épületen belül, és szegregált, ha minden más térrel mély kapcsolata van. Fontos, hogy az integráltság nem feleltethető meg egyértelmủen metrikus távolságoknak, és nemcsak az egyes tereket lehet jellemezni integrációs értékkel, hanem adható átlagos integrációs érték az egész épületre vagy nagyobb környezetre, például városrészre is." (Dúll, 2007. 53. o.)

A térszintaxis (Hillier, 1996) elméletének - a környezetpszichológiai szociofizikai környezet fogalmával egybecsengő - meghatározó gondolata, hogy a térhasználat és adott társadalmi folyamatok kölcsönösen hatnak egymásra. Ennek köszönhetően bizonyos téri elrendezések kedveznek egyes viselkedéseknek, míg másokat szinte lehetetlenné tesznek (Bafna, 2003). Erre példa, hogy hierarchikus társadalmi berendezkedést tükröz, ha a vezetőség eléréséhez több szobán kell áthaladnia annak, aki ügyét el szeretné intézni. Ebben az esetben ez az „akadálypálya” is hangsúlyozza a résztvevők közötti státuszkülönbséget.

A térszintaxis a környezet geometriai, konfigurációs felépítését vizsgálja (Hillier, 1996): az egyes térrészek közötti kapcsolatok különböző mértékben teszik lehetővé, hogy a térrészek mennyire elérhetőek, ill. mennyire láthatóak. Az elérhetőség arra utal, hogy fizi- 
Óvodás gyermekek csoportszobai térhasználatának vizsgálata a térszintaxis módszerével

kailag mennyire egyszerűen megközelíthető egy térrész (pl. egy épületen belül hány szobán kell átmenni, hogy elérjünk a célunkhoz, vagy milyen nagy távolságot kell megtennünk, hogy elérjük a csoportszobában a számunkra éppen szükséges játékot). A láthatóság pedig a belátható területre, azaz a legmesszebbi még éppen látható térrészre vonatkozik. Mind a láthatóság, mind az elérhetőség befolyásolja viselkedésünket (Hillier $\mathcal{E}$ Penn, 1991; Hillier, 1996) és interakcióinkat (Hillier E Hanson, 1984; Peponis, 1985; Hillier, 1996; Kupritz, 2003). A térszintaxis nem csak elméleti keretet kínál, hanem a gyakorlati alkalmazás elősegítésére mérőszámokat is használ a konstruktumok vizsgálatára, melyek kiszámításához az alaprajzra van szükség, valamint pl. a DepthmapX programra ${ }^{1}$ (Turner, 2004).

Az ún. integrált térrészek könnyen elérhetőek és láthatóak (Behbahani, Gu E Ostwald, 2014), így nagyobb kontrollt adnak a térhasználónak (pl. Mumcu, Düzenli E Özbilen, 2010), mivel jobban belátja, „uralja” a területet az adott ponton állva. Ez a kontroll rendkívül fontos csoportszobai környezetben, hiszen a gyerekek biztonsága érdekében mindenképpen szükség van arra, hogy az óvodapedagógus ennek a kontrollnak mindig birtokában legyen, illetve a gyermekeknek is szüksége van arra, hogy az óvodapedagógust mindig elérhetőnek érezzék. Egy óvodapedagógussal szemben elvárás, hogy a csoportszobában ne legyen háttal a gyerekeknek, legalábbis ne tartósan (ld. fent). Térszintaktikai szempontból megfogalmazva az óvodapedagógus a csoportszobának jól látható és jól megközelíthető, vagyis integrált térrészeiben tartózkodjon. A csoportszobák alapvető paramétereinek (pl. alaprajz, belmagasság, ablakok, ajtók mérete) megváltoztatására az óvodapedagógusoknak általában nincs lehetősége, a közösségi tervezés (Szabó, 2010) ezen a területen nem elterjedt. Azonban a bútorok elrendezése gyakran nagyban az óvodapedagógusoktól függ, ezzel pedig nagyban megváltoztathatják a csoportszoba

\footnotetext{
1 Letölthetö: http://otp.spacesyntax.net/software-andmanuals/depthmap/ (2019. 12. 22.)
}

használatát és így bizonyos mértékig annak térszintaktikai mutatóit is. Hiszen a használat szempontjából a bútorok tereptárgyaknak tekinthetőek, és így a mozgást és az átláthatóságot akadályozhatják. Természetesen bizonyos berendezési tárgyak a csoportszobában adottak, illetve elengedhetetlenek (asztalok, székek stb.), de ezek elhelyezése befolyásolja a csoport múködését. Érdemes a csoportszobák berendezésénél átgondoltan, a mindennapi tevékenységek hordozta elvárásoknak megfelelően, kényelmesen kialakítani azt. A megfelelően funkcionáló, jól használható terekben a gyermekek rendeltetésszerüen használják a játékszereket, kevesebb a konfliktus (Pálfi, é.n.). Ilyen terekben explicit és implicit módon egyaránt pozitív irányba terelhetjük az óvodai csoport tevékenységeit, fejleszthetjük a gyermekek képességeit (Nash, 1981), környezeti kompetenciáit (Pálfi, é.n.; Dúll, 2007).

A gyermekek térhasználata más szempontokat is felvet. A gyermekek számára az elbújást, elmélyült játékot lehetővé tevő terek esetleg pont olyan térrészek, melyekre kevésbé lát rá az óvodapedagógus, vagy a csoporttársak (például egy épített bunker, kuckó). A csoportszobában megjelenő túl sok inger elől történő elvonulást lehetővé tevő helyek különösen fontosak lehetnek például az autisztikus gyermekek számára (Nguyen, 2008, idézi Szabó és Szokolszky, 2015).

A látszólagos ellentétet a pedagógusok kontroll igénye és a gyermekek alkalmankénti elbújási szükséglete között a méretbeli különbségek tudják „feloldani”. A csoportszobákban az egyes játékterek elkülönítésére, szétválasztására használt polcok, bútorok gyakran valamivel a gyermekek szemmagassága fölé érnek, így a számukra külön térrészként megjelenő játéktereket a náluk magasabb felnőtt egy térként kezelheti. Ehhez hasonló kontrollt ad, amikor a csoportszobában elhelyezett nyitott polcokon az óvodapedagógus akár ülve is átlát.

Az óvodai csoportszoba használatnak van egy jellemzője, ami térszintaktikai szempontból nagy kihívást jelent, ez pedig nem más, mint hogy a csoportszobák berendezését az egyes tevékenységekhez (pl. dalos körjáték, 
dramatizálás) kisebb-nagyobb mértékben az óvodapedagógusok átrendezik. Azonban a csoportszobáknak általában van egy „alap elrendezése", amit az egyes feladatokhoz, tevékenységekhez való átrendezés után visszaállítanak. Tehát ugyan van némi változatosság a bútorok elhelyezkedésében és így a térszintaktikai mutatókban is, a szabadjáték alatti csoportszobai elrendezést tekinthetjük általános, a gyerekek és az óvodapedagógusok számára is megszokott, alap elrendezésnek.

\section{Kutatási cél}

Jelen tanulmányunkban bemutatott kutatásunk célja annak feltárása volt, hogy a térszintaxis-mutatók alapján milyen mértékben lehet elővételezni, előzetesen bejósolni a viselkedést egy olyan térszintaktikai szempontból specifikus környezetben, mint az óvodai csoportszoba, egy specifikus mintán (óvodás gyerekek és óvodapedagógusok). Vagyis arra voltunk kíváncsiak, hogy a térszintaktikai mutatók összefüggést mutatnak-e azzal, hogy melyik térrészeket használják intenzívebben az óvodások és a pedagógusok. A vizsgálat további célja volt, hogy a gyermekek és a felnőttek közötti térhasználatbeli különbségeket, illetve azok térszintaktikai mutatókkal való kapcsolatait feltárja.

\section{Módszer}

Kutatásunkban - ahogy korábban említettük - a természetes megfigyelés módszerét alkalmaztuk. Ez a módszer kifejezetten alkalmas az óvodáskorú gyermekek viselkedésének vizsgálatára. Óvodai csoportszobákban készítettünk videófelvételeket a csoportszobai tevékenységről. A felvételeken látottakat a térhasználat szempontjából kódoltuk. Majd a megfigyelt térhasználatot összevetettük a térszintaxis mutatókkal.

Az Eötvös Loránd Tudományegyetem Etikai Bizottsága 2015-ben engedélyezte kutatásunkat (az engedély száma: 2015/229). A vizsgálat lebonyolításához, videóanyagok készítéséhez pedig mind az óvodák vezetése és az óvodapedagógusok, mind a gyermekek szülei is hozzájárultak.

\section{Vizsgálati személyek}

A megfigyelést 3 óvodában végeztük, 3 csoportszobában (a továbbiakban „A”, „B” és „C” csoportszoba). A megfigyelt csoportok közül életkor tekintetében kettő heterogén és egy homogén, középső csoport volt. Mindegyik csoport integráló volt, 1-3 sajátos nevelési igényü óvodással. A csoportokban a délelőttös óvodapedagógus és alkalmanként a dajka volt jelen.

\section{Helyszín: a csoportszobák}

A kutatásban két budapesti óvoda 3 csoportszobájában megfigyelt viselkedést elemezzük. A csoportszobák között természetesen vannak hasonlóságok pl. alapterület, ablakok száma, rendelkezésre álló bútorok típusa és mennyisége stb. tekintetében. Azonban az elrendezésben különbségek jelentkeznek, amelyek a térhasználati szokásokat erősen befolyásolhatják, illetve ezek a különbségek a különböző csoportszobákban eltérő térszintaxis mutató mintázatot eredményeznek. Az alaprajzokat a helyszín (falak, nyílászárók, bútorok) pontos lemérése után készítettük el. A csoportszobák szabad játék ideje alatt jellemző alap elrendezése (ld. fent) jelenik meg a használt alaprajzokon, a kutatás során segítségünkre volt az alaprajzokon az egyes játéktereket bejelölése (ld. 1. ábra).

\section{Eljárás}

A csoportszobák térszintaktikai mutatóit a DepthmapX program (Turner, 2004) segítségével számoltuk ki. A térszintaktikai mutatók kiszámításához a három csoportszoba alaprajzára volt szükségünk. A kutatásban használt térszintaktikai mutatók kialakításakor a gyermekek szemmagassága volt irányadó. Ezenkívül az asztalok voltak meghatározó tényezők, hiszen ezek az átlátást ugyan lehetővé teszik, de az egyes térrészek megközelíthetőségét megakadályozzák. 
Óvodás gyermekek csoportszobai térhasználatának vizsgálata a térszintaxis módszerével

a)

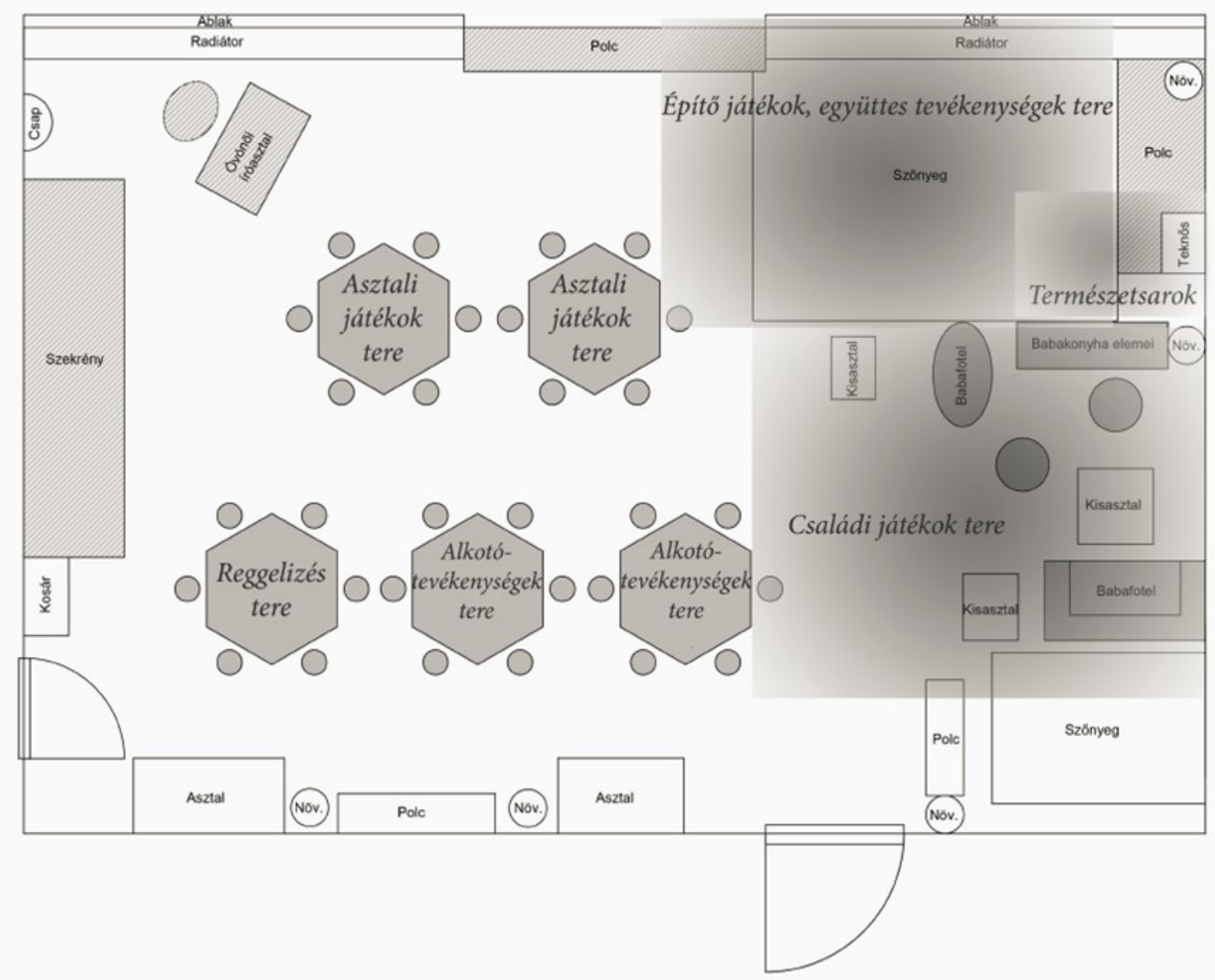

b)

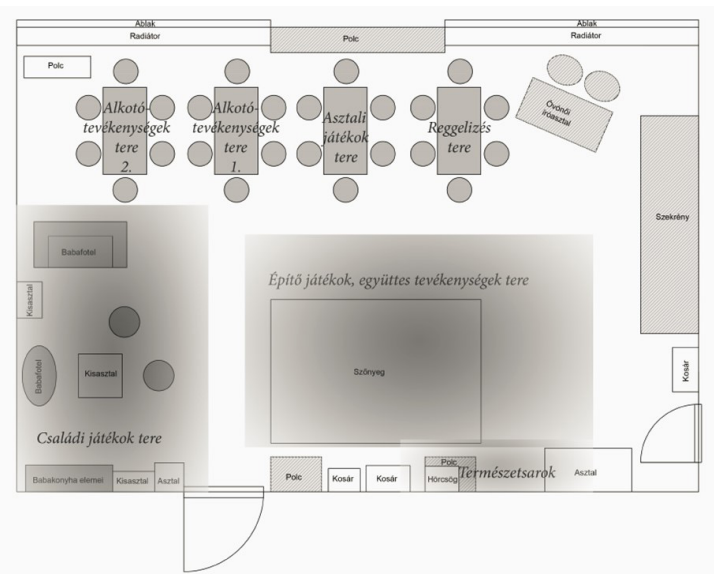

c)

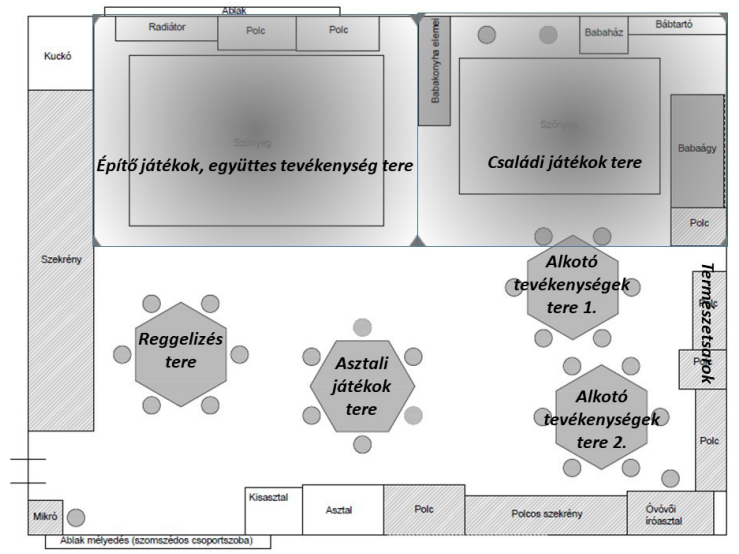

1. ábra: (a, b, c): $A z$ „A” „, $B$ ”és "C" csoportszobák alaprajzai a bútorok és játékterek megjelölésével

Az alaprajzoknak kétféle verzióját használtuk: egyiken az összes bútor szerepelt, mint tereptárgy (ld. 2. ábra), a másikon csak a gyerekek szemmagasságánál magasabb bútorok. A térszintaktikai mutatók számításánál ezek a tereptárgyak, mint átláthatatlan, falszerü elemek jelentek meg az alaprajzon (ld. 3. ábra). Az összes bútort ábrázoló verzió, illetve az ezzel számolt térszintaktikai mutatóval az egyes térrészek elérhetőségét írtuk le, míg a csak a gyerekek szemmagasságnál magasabb bútorokat tartalmazó alaprajz és az az alapján képzett mutató a láthatóságot definiálta.

A csoportszobák térszintaktikai elemzése során az ún. láthatósági gráf (visibility graph) mutatót használtuk. A mutató azt közli, hogy az egyes térrészekből hány darab másik térrészt lehet látni. A számításokhoz egy rácsot 
Keszei Barbara - Böddi Zsófia - Dúll Andrea

helyez a program az alaprajzra, és így hozza létre az egyes térrészeket, amelyek között aztán a láthatósági viszonyokat számolja ki. A rács sűrűségét mi magunk állíthatjuk be. A rács méretét (tehát a gráf felbontását) az határozta meg, hogy a kódolóknak ezekben a térrészekben megjelenő viselkedést kell kódolni, tehát a térrészek nem lehettek túlzottan kicsik, mivel akkor a lehetetlen lett volna

a)

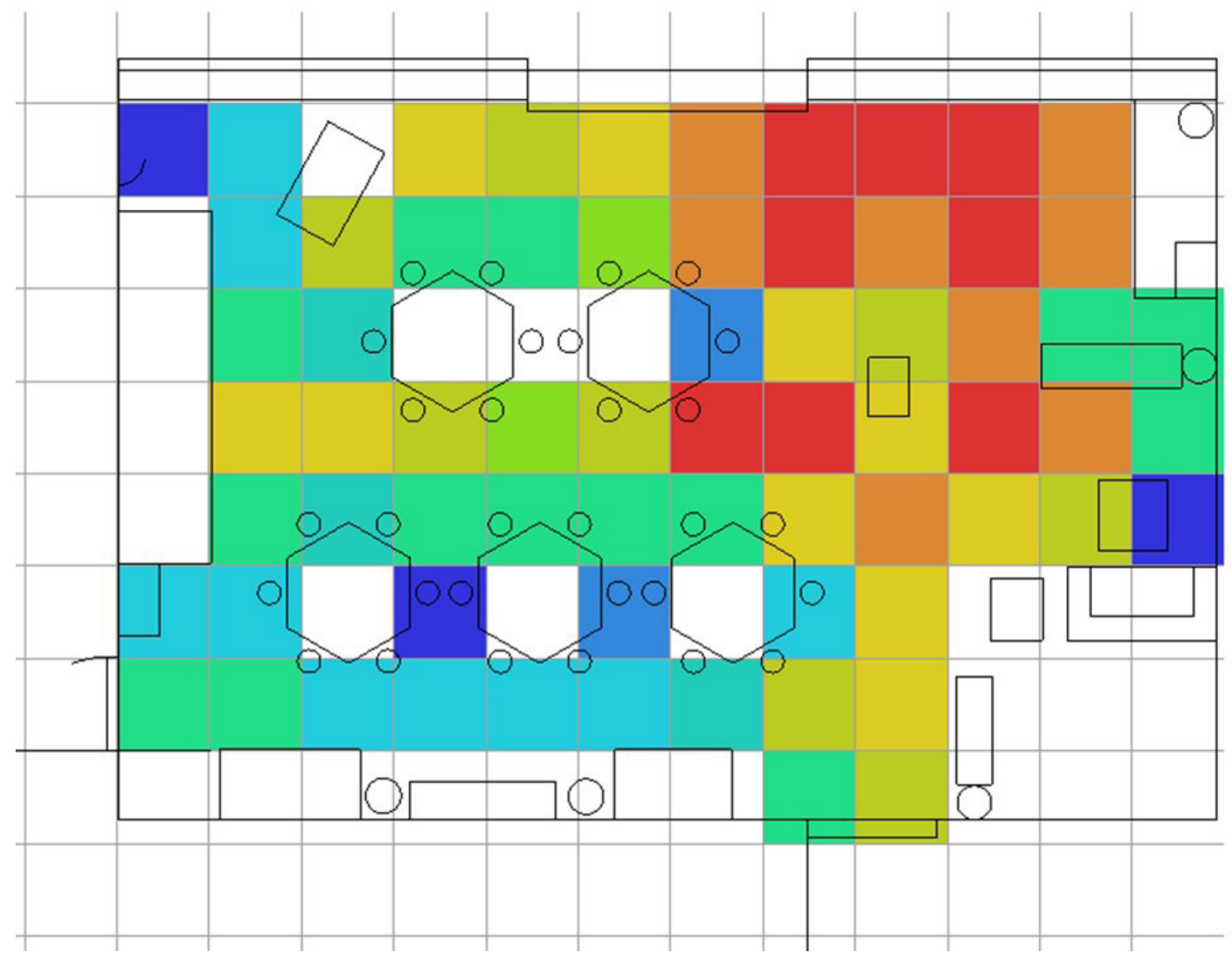

b)

c)
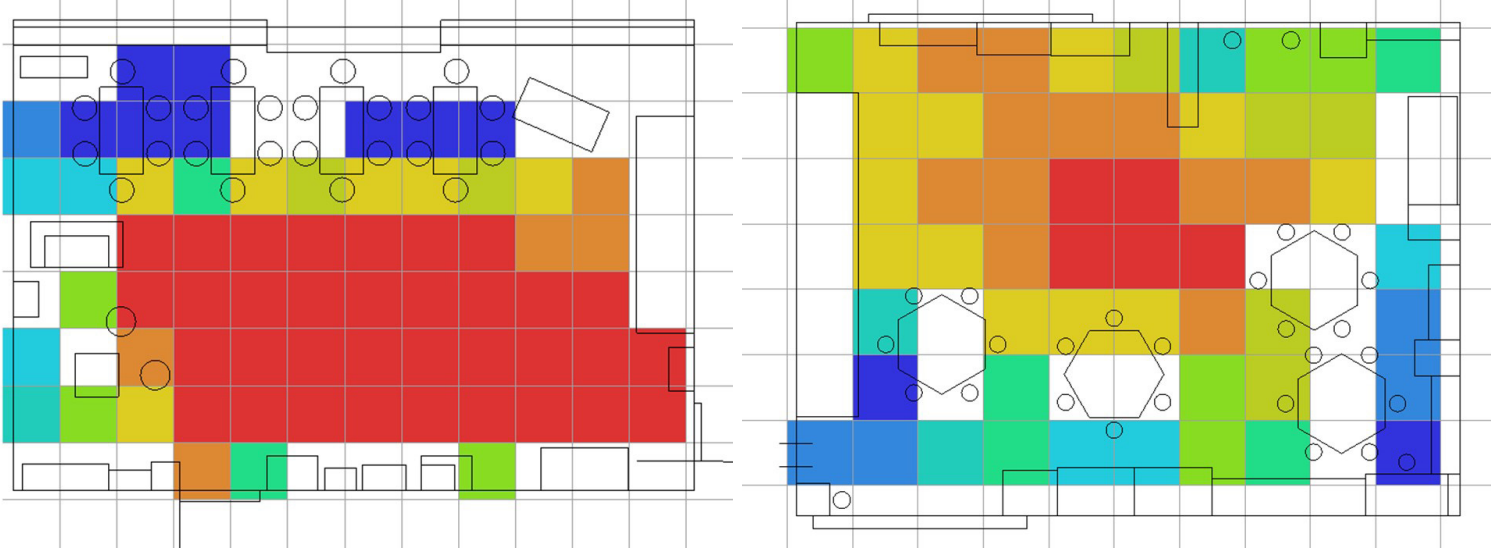

2. ábra: (a, b, c) A láthatósági gráfok az összes bútorral az „A”, „B” és „C” csoportszobában (a pirosas színek a magasabb, a kékes színek az alacsonyabb látatósági gráf értékeket jelölik) $l$ pontosan kódolni a térhasználatot, azonban kellőképpen nagy felbontásúnak kellett lennie ahhoz, hogy az egyes térrészek közötti láthatóságbeli különbségek ne mosódjanak el az alacsonyabb felbontás miatt. Egy-egy csoportszobát 90-96 térrészre osztottunk fel, a különbség a csoportszobák enyhén eltérő méretéből adódott (ld. 3. ábra). 
Óvodás gyermekek csoportszobai térhasználatának vizsgálata a térszintaxis módszerével

a)

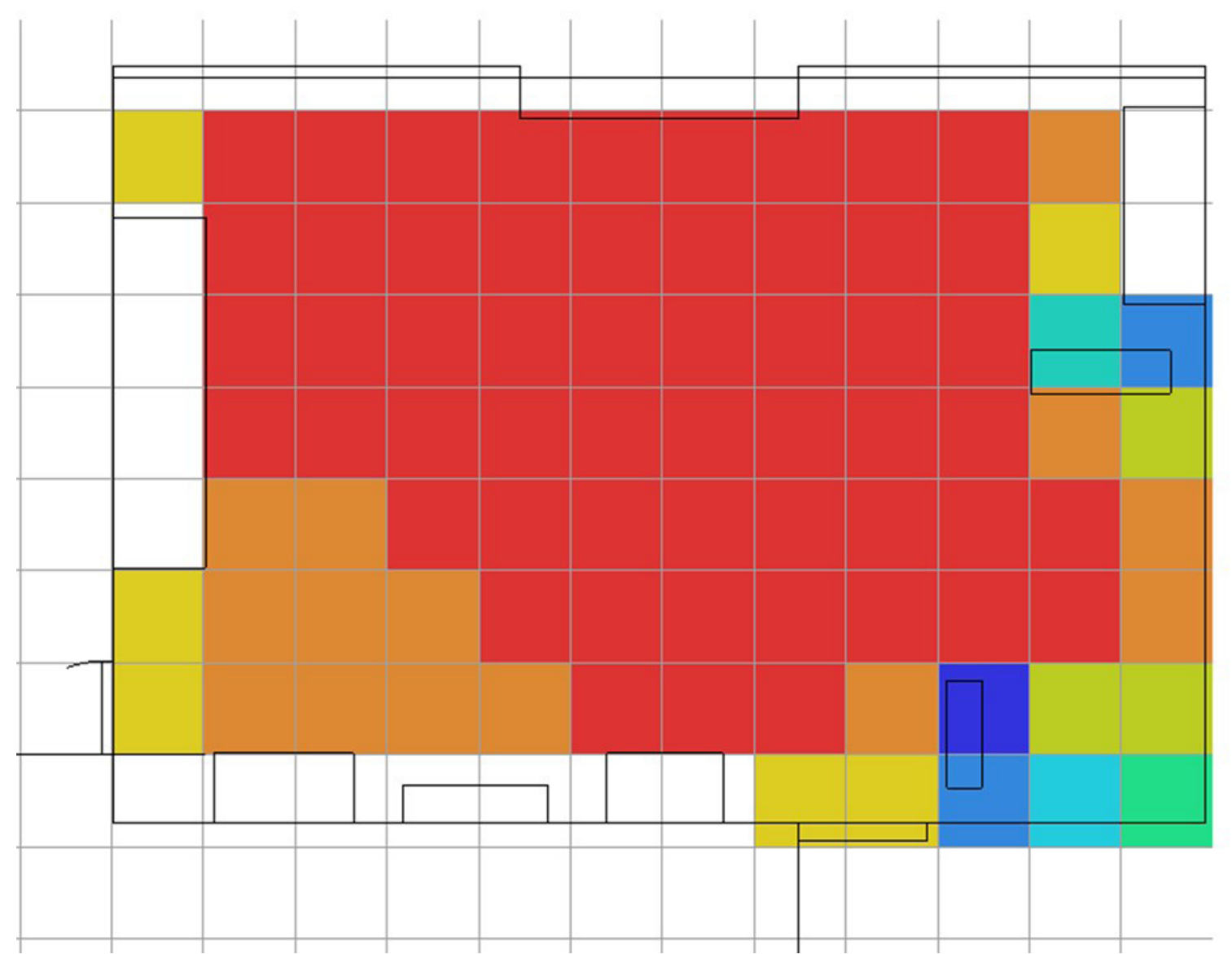

b)

c)
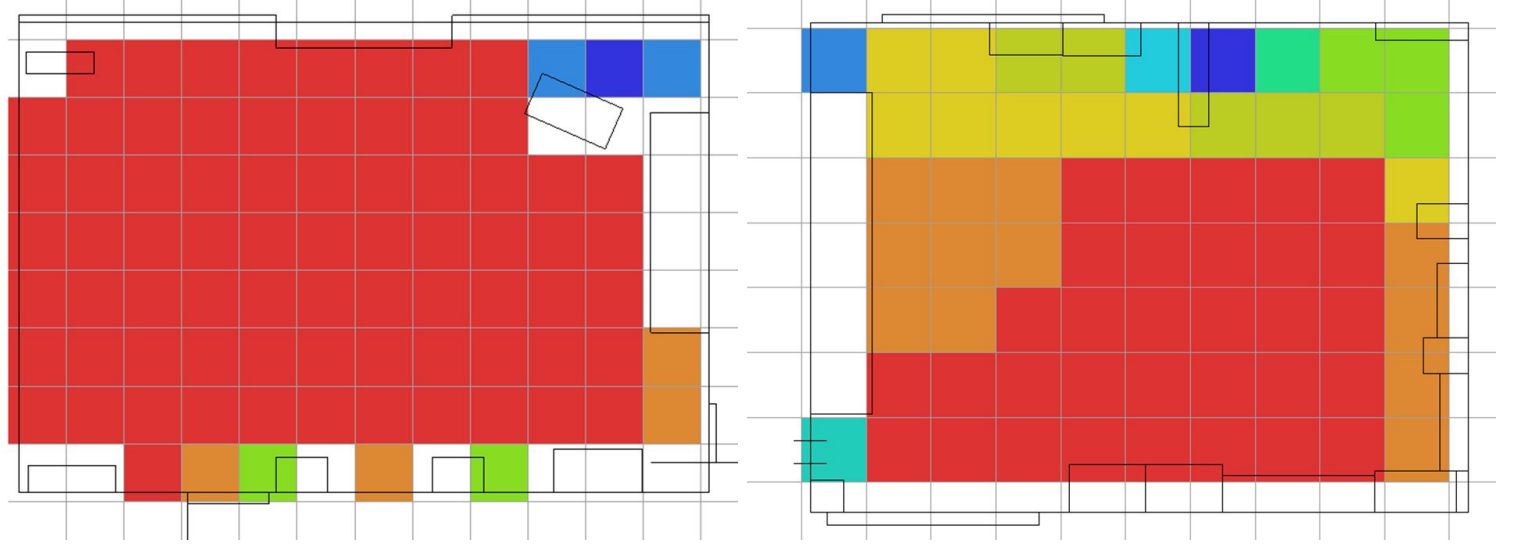

3. ábra: (a, b, c) A láthatósági gráfok a gyerekek szemmagasságánál magasabb bútorokkal az „A”, „B” és „C” csoportszobában. (a pirosas színek a magasabb, a kékes színek az alacsonyabb látatósági gráf értékeket jelölik)

\section{A videófelvételek}

A videófelvételeken a csoportszobák délelőtti tevékenységét rögzítettük. A megfigyelt időszakok 90 perc hosszúak voltak, azonban a kódolásra kiválasztott felvételeken csak a szabadjáték szerepelt, melyeken a csoportszobában a bútorok az alap elrendezés helyzetében voltak. Egy csoportban több alkalommal is vettünk fel videóanyagot.
A csoportszoba három pontján helyeztünk el kamerákat, így a csoportszoba szinten minden pontja látható volt legalább az egyik felvételen. A térszintaktikai mutatók számítása szempontjából fontos, hogy a tér minden pontjáról rendelkezzünk információval, hogy a megfelelő módon összehasonlíthassuk a térszintaktikai mutatókat és a megfigyelt viselkedéseket. A felvételek készítésekor, illetve a kamerák elrende- 
Keszei Barbara - Böddi Zsófia - Dúll Andrea

zésekor arra fordítottuk a legnagyobb figyelmet, hogy a csoportszoba játékterei mindenképpen láthatóak legyenek a felvételeken. Emiatt viszont egy-egy sarok (leggyakrabban az óvodapedagógus asztala) nem teljesen látszik a felvételeken. Mivel ezeken a térrészeken a megfigyelt időszakban tevékenység nem zajlott és sem gyermek, sem felnőtt nem használta azt, ezeket a területeket kihagytuk az elemzésből.

Korábbi tanulmányainkban az adatgyüjtés kihívásait és azok megoldási lehetőségeit részletesen bemutattuk (ld. Keszei, Böddi és Dúll, 2016; Böddi, 2017).

\section{A kódolás menete}

A kódolás során a kódolók nyomon követték, hogy egyes térrészekben, mezőkben, adott időszakban hány gyermek, illetve hány felnőtt tartózkodik. Az egyes térrészeket egy, az alaprajzon megjelenített négyzetrács segítségével különítettük el. A pontos kódoláshoz pedig a sakktáblához hasonlóan az egyes rubrikákat számok és betűk kombinációjának segítségével jelöltük (ld. 4. ábra).

a)

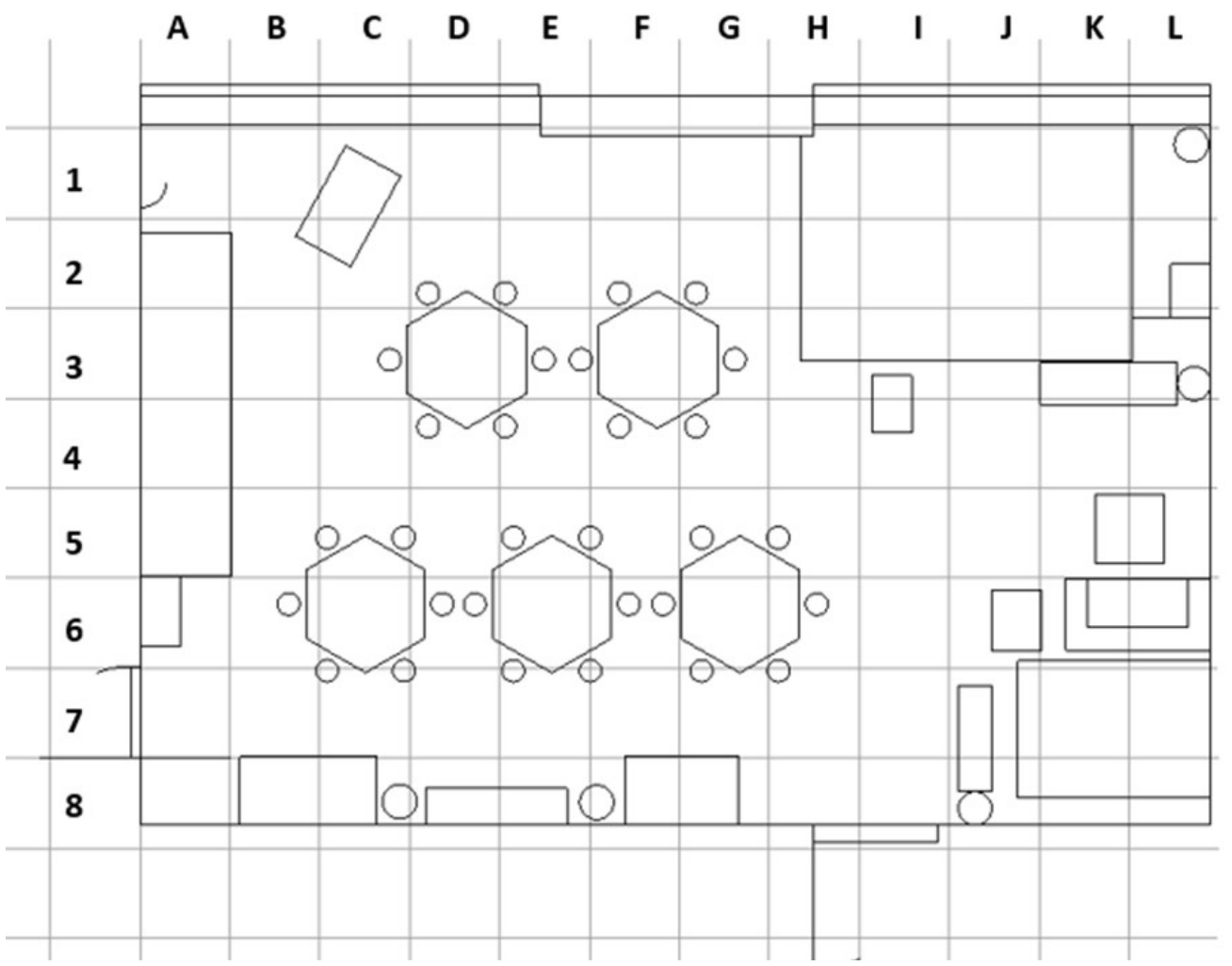

b)

c)

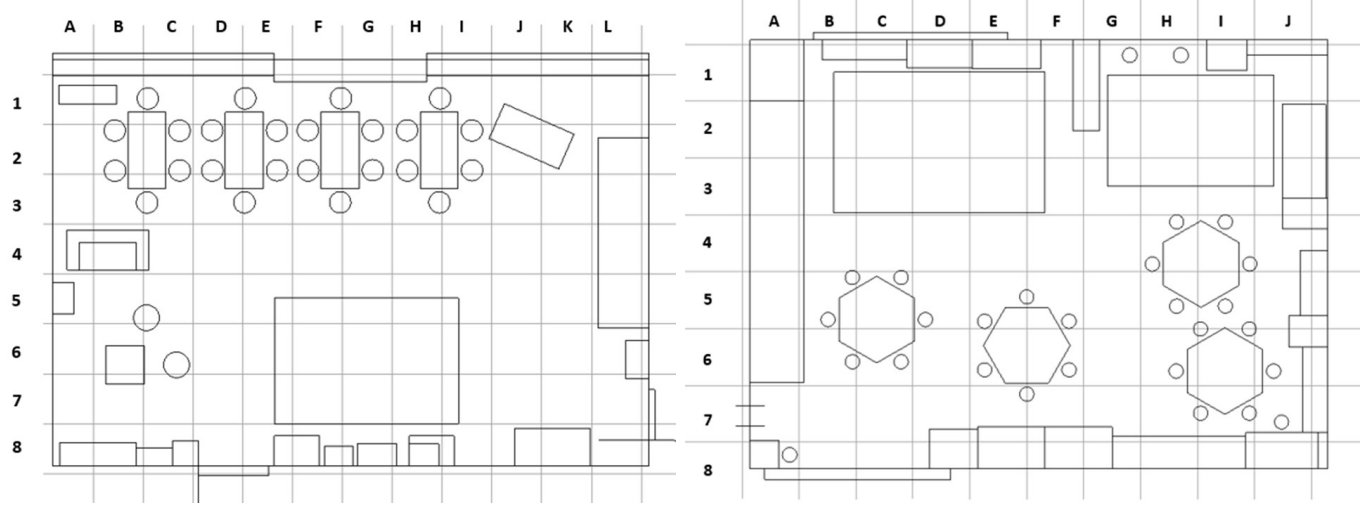

4. ábra: (a, b, c) A kódolást segítő alaprajzok az egyes térrészek megkülönböztetésére használt jelölésekkel az „A”, „B” és „C” csoportszobában 
Óvodás gyermekek csoportszobai térhasználatának vizsgálata a térszintaxis módszerével

A csoportszobai térhasználatot, történéseket videófelvételeken látták a kódolók. Egyegy csoportszobai felvételen általában három kameraállásból lehetett megfigyelni a gyerekek és a felnőttek viselkedését, és azt, hogy hol helyezkednek el a csoportszoba terében.

A kódolók a betanítás során megismerkedtek a vizsgálat koncepciójával, a térszintaxis alapjaival. A betanítás második lépéseként a különböző nézőpontból készült videófelvételeken és az alaprajzokon látható „tereptárgyakat” (asztalok, székek, szőnyeg széle stb.) a kódolókkal együtt beazonosítottuk az alaprajzon, amiről jegyzeteket is készíthettek. A kódolók hamar elsajátították, hogy hogyan egyeztessék a képernyőn látott, különböző nézőpontokból felvett videófelvételeket, az előttük látható alaprajzzal, illetve annak különböző térrészekre való felosztásával.

A betanítás következő lépéseként a kódolók megismerkedtek az adattáblával, melybe az egyes térrészek kódjai (A1, A2, A3 stb.) és az időkódok mentén kellett a térhasználatot jelölni. A kódolás megkönnyítése érdekében a gyerekek és a felnőttek térhasználatát külön adattáblákon rögzítették a kódolók.

A videóanyag korábbi, interakció fókuszú kódolása során hasznosnak bizonyult a felvétel 10 másodperc hosszúságú egységekre való bontása (Böddi, 2017). A kódolóknak tehát 10 másodperces szakaszokat kellett vizsgálnia. A VLC videólejátszó programban az Alt+jobbra nyíl billentyűkombináció segítségével tudták 10 másodpercnyivel léptetni a videót, majd megállítani azt, így gyakorlatilag állóképeken kellett a kódolóknak megszámolni, hogy hány gyerek, illetve hány felnőtt tartózkodik az adott mezőben az adott időkódnál.

Egy-egy kódoló egy csoportszoba egy délelőttjén megjelenő térhasználatot kódolta. Két csoportszobáról („B” és „C” csoportszoba) egy-egy délelőtt felvételét elemezték, míg az „A” csoportszobáról három felvételt is kódoltak a megfigyelők. A kódolás során a felvételeket 15 perces egységekre bontottuk, melyeknek első 5 percét kellett kódolni, így összesen egy-egy kódoló 15 percnyi tárhasználatot kódolt 10 másodperces szakaszokra bontva.
A kódolásban az ELTE TÓK öt hallgatója vett részt. A kódolók tehát nem építész hallgatók, vagy kifejezetten a design, 3D modellezésben jártas hallgatók, azonban nem tekinthetők laikusnak a módszertan tekintetében. Lévén mind az öten csecsemő- és kisgyermeknevelő szakos hallgatók, számos gyermek-, gyermek-pedagógus megfigyelési feladatot végeztek és végeznek képzésük során, így tapasztalattal rendelkeznek a megfigyelés módszerével kapcsolatosan. Ezt támasztotta alá az is, hogy a feladatot a betanítás és némi gyakorlás után könnyen el tudták végezni.

$\mathrm{Az}$ adatelemzést SPSS 24.0 statisztikai program segítségével végeztük. A kódolás után adattisztításra volt szükség, mivel a DepthmapX nem minden térrészhez számolt térszintaktikai mutatókat, ahova a kódolók a tevékenységet jelöltek. Ennek oka, hogy a DeptmapX a bútorokat „falnak” tekinti, így a programban az nem lehetséges, hogy az asztal fölött tevékenységet végezzenek. A betanítás során ez a probléma már felmerült, a kódolás folyamatában az asztalokon, az asztalok „fölött" végzett tevékenységet az asztal melletti rubrikában jelöljék. Így az adatok tisztításra csak néhány esetben volt szükség.

\section{Eredmények}

Kutatási kérdéseink arra irányultak, hogy a térszintaktikai mutatók milyen összefüggést mutatnak a mértékben a térhasználat intenzitásával, illetve arra, hogy milyen különbségek és hasonlóságok vannak a gyermekek és az óvodapedagógusok térhasználatában.

\section{A térhasználat leíró bemutatása}

A térhasználat vizsgálatára az egyes térrészekben a gyerekek, illetve a felnőttek előfordulási gyakoriságait mint folytonos változókat használtuk. Ezeket a gyakorisági adatokat az 1-6. összesitő táblázatok mutatják, a gyermekek térhasználata kapcsán az első 7, felnőttekében az első 5 leggyakrabban használt térrészt jelenítettük meg. 
Keszei Barbara - Böddi Zsófia - Dúll Andrea

\begin{tabular}{|c|l|c|c|c|}
\hline térrész kódja & \multicolumn{1}{|c|}{ térrész megnevezése } & funkció & gyakoriság & gyakoriság (\%) \\
\hline F6 & alsó sor jobb szélső asztal & alkotó tevékenység & 444 & 9 \\
\hline E5 & alsó sor középső asztal & alkotó tevékenység & 422 & 8 \\
\hline D6 & alsó sor bal oldali asztal & reggelizés & 355 & 7 \\
\hline D5 & alsó sor középső asztal & alkotó tevékenység & 341 & 7 \\
\hline F5 & alsó sor középső asztal & alkotó tevékenység & 304 & 6 \\
\hline F4 & felső sor jobb oldali asztal & asztali játékok & 271 & 5 \\
\hline K2 & építő szőnyeg fal felőli része & építő játékok & 217 & 4 \\
\hline
\end{tabular}

1. táblázat: Az „A” csoportszobában a gyermekek által leggyakrabban használt 7 térrész

\begin{tabular}{|c|l|c|c|c|}
\hline térrész kódja & \multicolumn{1}{|c|}{ térrész megnevezése } & funkció & gyakoriság & gyakoriság (\%) \\
\hline C3 & felső sor bal oldali asztal & asztali játékok & 92 & 25 \\
\hline D6 & alsó sor bal oldali asztal & reggelizés & 41 & 11 \\
\hline C7 & alsó sor középső asztal & alkotó tevékenység & 29 & 8 \\
\hline H5 & alsó sor jobb szélső asztal & alkotó tevékenység & 29 & 8 \\
\hline D5 & alsó sor középső asztal & alkotó tevékenység & 20 & 5 \\
\hline
\end{tabular}

2. táblázat: Az „A” csoportszobában a felnőttek által leggyakrabban használt 5 térrész

\begin{tabular}{|c|l|c|c|c|}
\hline térrész kódja & \multicolumn{1}{|c|}{ térrész megnevezése } & funkció & gyakoriság & gyakoriság (\%) \\
\hline F7 & építő szőnyeg közepe & építő játékok & 304 & 12 \\
\hline I2 & bal szélső asztal bal oldali széke & alkotó tevékenységek & 238 & 10 \\
\hline H6 & építő szőnyeg közepe & építő játékok & 122 & 5 \\
\hline H2 & jobb szélső asztal bal oldali része & reggelizés & 121 & 5 \\
\hline E7 & építő szőnyeg ajtóhoz közeli része & építő játékok & 112 & 4 \\
\hline C3 & bal szélső asztal terem közepe felé levő széke & alkotó tevékenységek & 104 & 4 \\
\hline H7 & építő szőnyeg fal felőli része & építő játékok & 99 & 4 \\
\hline
\end{tabular}

3. táblázat: A „B” csoportszobában a gyermekek által leggyakrabban használt 7 térrész

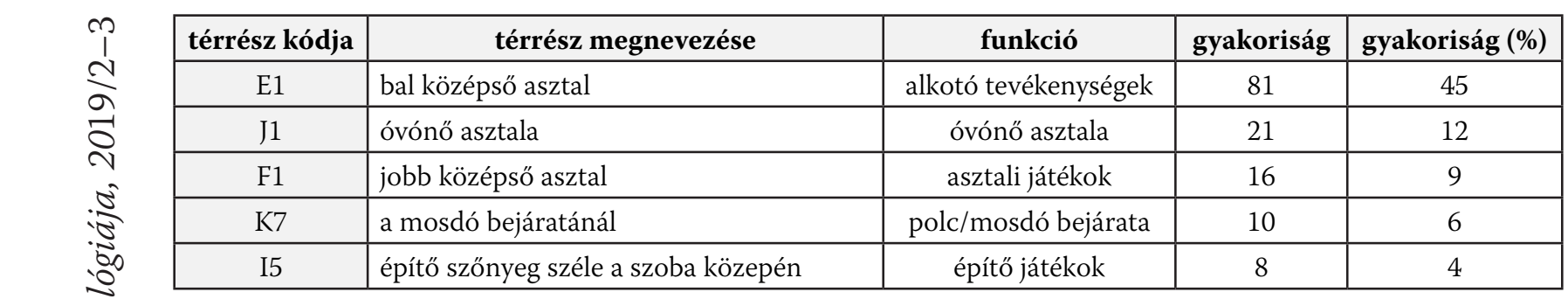

4. táblázat: A „B” csoportszobában a felnőttek által leggyakrabban használt 5 térrész

\begin{tabular}{|c|l|c|c|c|}
\hline térrész kódja & \multicolumn{1}{|c|}{ térrész megnevezése } & funkció & gyakoriság & gyakoriság (\%) \\
\hline A1 & kuckó & kuckó & 132 & 13 \\
\hline D5 & bal szélső asztal & reggelizés & 95 & 10 \\
\hline E2 & építő szőnyeg jobb oldala & építő játékok & 65 & 7 \\
\hline E6 & bal középső asztal & asztali játékok & 64 & 6 \\
\hline C5 & bal szélső asztal & reggelizés & 53 & 5 \\
\hline C2 & építő szőnyeg & építő játékok & 44 & 4 \\
\hline C6 & bal szélső asztal & reggelizés & 40 & 4 \\
\hline
\end{tabular}

5. táblázat: A „C” csoportszobában a gyermekek által leggyakrabban használt 7 térrész 
Óvodás gyermekek csoportszobai térhasználatának vizsgálata a térszintaxis módszerével

\begin{tabular}{|c|l|c|c|c|}
\hline térrész kódja & \multicolumn{1}{|c|}{ térrész megnevezése } & funkció & gyakoriság & gyakoriság (\%) \\
\hline B6 & bal szélső asztal ajtó felöli széke & reggelizés & 64 & 41 \\
\hline C6 & bal szélső asztal & reggelizés & 36 & 23 \\
\hline F6 & bal középső asztal & asztali játékok & 31 & 20 \\
\hline E7 & bal középső asztal & asztali játékok & 7 & 4 \\
\hline D7 & két bal oldali asztal között a fal mellett & polc & 6 & 4 \\
\hline
\end{tabular}

6. táblázat: A „C" csoportszobában a felnőttek által leggyakrabban használt 5 térrész

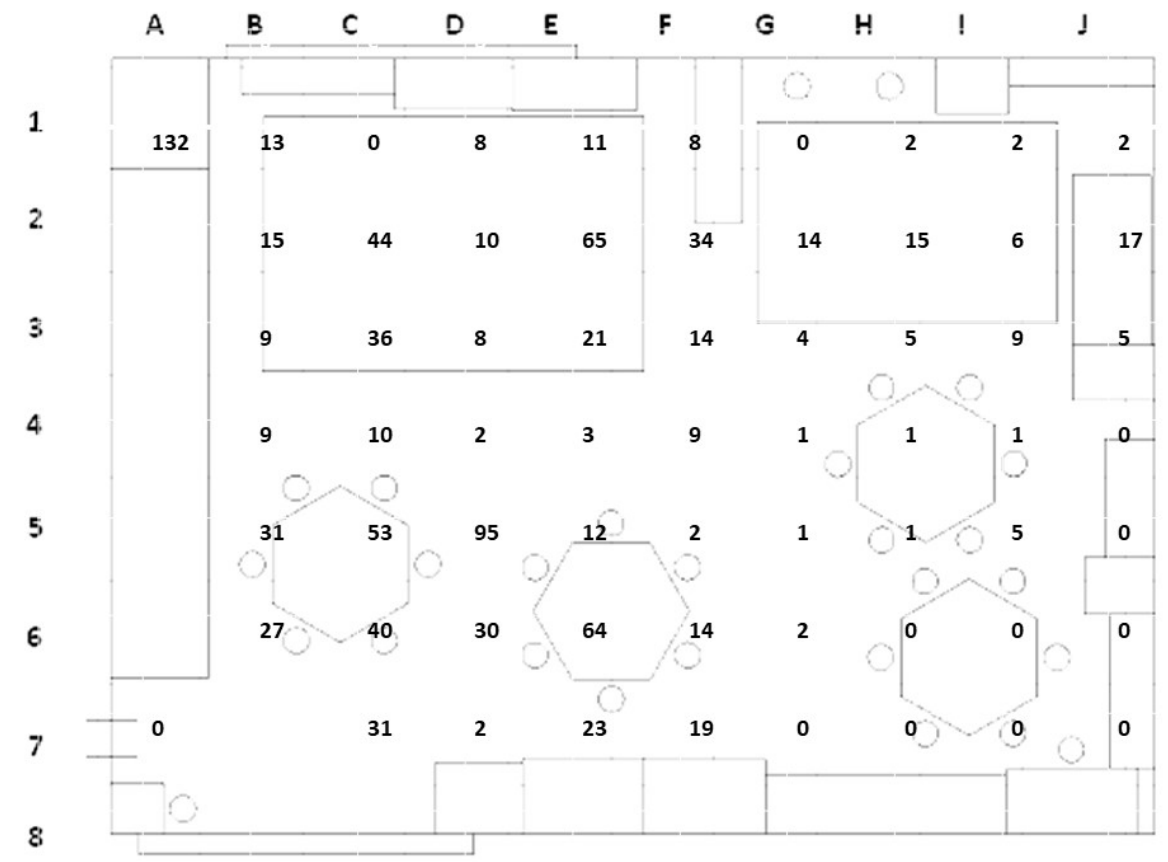

5. ábra: A gyermekek térhasználatának gyakorisági adatai az alaprajzra vetítve a „C” csoportszobában

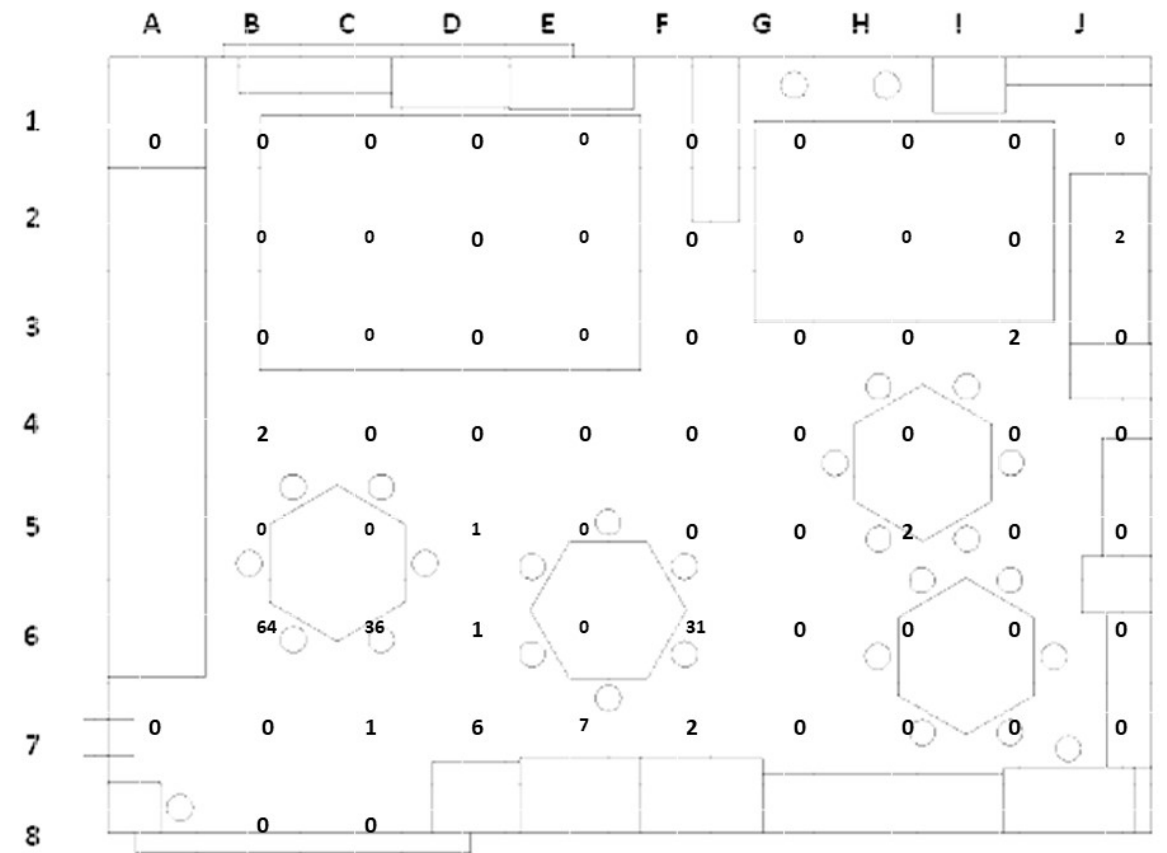

6. ábra: A felnőttek térhasználatának gyakorisági adatai az alaprajzra vetítve a „C” csoportszobában 
A gyerekek térhasználatában az alkotó tevékenységek tere és az asztali játékok terei a leggyakrabban használt terek, illetve asztalok (ld. 5. ábra gyakorisági adatai). Ennél a térhasználói csoportnál megjelenik, ugyan jóval alacsonyabb számban, az építő játékok terének használata, valamint az „A” csoport egyik megfigyelt napján a gyakran használt terek között jelent meg a családi játékok tere is. A "C" csoportszoba A1-es térrészében (ld. 5/c ábra) található kuckó a csoportban leggyakrabban használt térrész volt. A gyerekek teljes térhasználatának 13,2\%-a erre a térre koncentrálódott. Ezt a térrészt 24 esetben, vagyis 24, 10 másodperces megfigyelési szakaszban használta egyedül egy gyerek, 33 esetben ketten, 10 esetben hárman, 3 esetben négyen és mindössze 54 esetben nem volt „lakója” a kuckónak, tehát a vizsgált esetek több mint felében a kuckót egy vagy több gyerek használta és a legkedveltebb helye volt a csoportszobának.

A felnőttek legintenzívebben használt terei között elsősorban az alkotó tevékenységek tere és az asztali játékok terei jelentek meg, csakúgy, ahogy a gyerekeknél (ld. 6. ábra). Az általunk használt kódolásból nem derül ki, hogy ezeken a térrészeken ültek vagy álltak-e az óvodapedagógusok. Egy-egy csoportszobában az óvodapedagógus sokat volt az ajtó, illetve az íróasztala mellett. Az ajtó közelében a reggeli-délelőtti időszakban nyilvánvalóan azért tartózkodott az óvodapedagógus, mert úgy helyezkedett el, hogy mindenképp rálásson az ajtóra, és fogadhassa az érkező gyermekeket, kommunikálhasson a szülőkkel. Ez az óvodai napban a szabadjáték ideje alatt is nagyon fontos eleme a pedagógiai munkának. Az íróasztalnál feltehetően azért tartózkodtak a pedagógusok, mert a szabadjáték idejében valamennyi adminisztrációt is végeztek (például regisztrálták, ki érkezett meg aznap az óvodába), esetleg mivel a gyermekek elmélyülten játszottak, a háttérbe húzódva figyelték őket.

\section{A gyermekek és felnöttek térhasználata közöti összefüggések}

A gyermekek és a felnőttek térhasználata nem mutatott szignifikáns összefüggést a vizsgálatunkban. Sem az egyes csoportszobák, sem az összesített eredmények nem támasztják alá, hogy az óvodapedagógus és az óvodások a térnek ugyanazon pontjait használnák.

A felnőtt és gyermek térhasználat gyakoriságai közötti korrelációk számításakor folytonos változókként tekintettünk a gyakorisági adatokra. A felnőttek esetében a változó azonban inkább tekinthető dichotómnak, mivel a csoportszobában leggyakrabban egy, esetenként két felnőtt tartózkodott. A felnőtt jelenléte folytonos változót dichotóm változóvá alakítva (egy vagy több felnőtt az adott térrészben (82 eset) vagy nincs felnőtt (414 eset), akkor az eredmények azt mutatják, hogy abban a térrészben ahol a felnőtt vagy felnőttek vannak, több gyermek tartózkodik $(t(109,5)=-2,505, p=0,014)$.

A felnőttek térhasználatát a térszintaktikai mutatókkal összevetve azt állapíthatjuk meg, hogy a felnőttek azokon a térrészeken fordultak meg gyakrabban melyek mind a magas bútorokkal $(\mathrm{t}(159,1)=-2,208, \mathrm{p}=0,029)$, mind pedig - ugyan csak tendenciaszinten - a minden bútorral számított láthatósági gráfokon $(t(109,5)=-1,746, p=0,084)$ magas értékeket kapnak. Érdekesség, hogy ez az eredmény a "C" csoportszoba esetében nem jelenik meg. A „B” csoportnál a tendencia szintü kapcsolat áll fenn a minden bútort láttató láthatósági gráfokon $(\mathrm{t}(37,9)=-1,769, \mathrm{p}=0,085)$.

$\mathrm{Az}$ „A” csoportban, ahol 3 megfigyelés eredményeit is elemeztük szignifikáns különbségeket találhatunk a gyermekek térhasználatával összefüggésben $(\mathrm{t}(65,4)=-$ 2,668, $\mathrm{p}=0,010)$. Ebben a csoportszobában a felnőttek térhasználata és a magas bútorokkal számoló láthatósági gráf között egy erős tendencia jellegű, majdnem szignifikáns különbséget találunk. Az összefüggések iránya természetesen minden esetben megegyezik az összes csoportszoba adatait használó elemzés eredményeivel. 
Óvodás gyermekek csoportszobai térhasználatának vizsgálata a térszintaxis módszerével

\section{A gyermekek és felnöttek}

térhasználatának összefüggései a térszintaktikai mutatókkal

Az „A” csoportszobában a gyermekek térhasználata szignifikáns pozitív kapcsolatot mutatott a magas bútorokkal számolt láthatósági gráffal, ami a csoportszobán belül láthatóságot mutatta. Vagyis a gyermekek azokat a térrészeket használták intenzívebben, melyek könnyen láthatóak a csoportszoba más pontjaiból is. Az óvodapedagógusra - mint felnőtt térhasználóra vonatkozó változó - viszont az összes bútorral számolt láthatósági gráffal mutatott negatív szignifikáns kapcsolatot. Ennek értelmében a felnőttek olyan térrészeken tartózkodtak többet, melyek nehezebben elérhetőek (ld. 1. táblázat).

\begin{tabular}{|c|c|c|c|c|c|}
\hline & & $\begin{array}{c}\text { "A" } \\
\text { csoportszoba } \\
\text { gyermek } \\
\text { térhasználók }\end{array}$ & $\begin{array}{c}\text { "A” } \\
\text { csoportszoba } \\
\text { felnőtt } \\
\text { térhasználók }\end{array}$ & $\begin{array}{c}\text { „A” } \\
\text { Csoportszoba } \\
\text { láthatósági gráf } \\
\text { összes bútorral } \\
\end{array}$ & $\begin{array}{c}\text { „A" } \\
\text { csoportszoba } \\
\text { láthatósági } \\
\text { gráf magas } \\
\text { bútorokkal } \\
\end{array}$ \\
\hline \multirow{3}{*}{$\begin{array}{l}\text { „A” csoportszoba } \\
\text { gyermek } \\
\text { térhasználók }\end{array}$} & Pearson korreláció - r & 1 & ,056 &,- 047 &, $118^{*}$ \\
\hline & Szign. (2-szélű) & & ,271 & ,402 & ,019 \\
\hline & $\mathrm{N}$ & & 395 & 320 & 395 \\
\hline \multirow{3}{*}{$\begin{array}{l}\text { „A" csoportszoba } \\
\text { felnőtt } \\
\text { térhasználók } \\
\text { (óvodapedagógus) }\end{array}$} & Pearson korreláció - r & & 1 &,$- 139 *$ & 021 \\
\hline & Szign. (2-szélű) & & & ,013 & 670 \\
\hline & $\mathrm{N}$ & & & 320 & 395 \\
\hline \multirow{3}{*}{$\begin{array}{l}\text { „A” csoportszoba } \\
\text { Láthatósági gráf } \\
\text { összes bútorral }\end{array}$} & Pearson korreláció - r & & & 1 &, $135^{*}$ \\
\hline & Szign. (2-szélü) & & & & ,016 \\
\hline & $\mathrm{N}$ & & & & 320 \\
\hline
\end{tabular}

*. $\mathrm{p}<0,05$ szignifikancia szint (2-szélű)

7. táblázat: Az „A” csoportszoba adatainak korrelációs együtthatói

A „B” csoportszobában megfigyelt gyermeki viselkedés nem mutatott szignifikáns kapcsolatot a tészintaktikai mutatókkal. Egy tendenciaszintü kapcsolatot találtunk a felnőttek térhasználata és az összes bútorral készített láthatósági gráf között (ld. 2. táblá$z a t)$. Azonban ez a gyenge kapcsolat ellentétes irányba mutat, mint az „A” (ld. 1 táblázat) vagy a „C” (ld. 3. táblázat) csoportszobában megfigyelt szignifikáns együttjárások. A „C" csoportszobában ezenkívül egy tendencia szintet majdnem elérő összefüggést találtunk, ami viszont ellentétes irányú az „A" csoportszobában megfigyelt gyermek térhasználat és láthatósági gráf magas bútorokkal változó között.

\begin{tabular}{|c|c|c|c|c|c|}
\hline & & $\begin{array}{c}\text { „B” } \\
\text { csoportszoba } \\
\text { gyermek } \\
\text { térhasználók } \\
\end{array}$ & $\begin{array}{c}\text { „B” } \\
\text { csoportszoba } \\
\text { felnőtt } \\
\text { térhasználók }\end{array}$ & $\begin{array}{c}\text { „B” } \\
\text { csoportszoba } \\
\text { láthatósági } \\
\text { gráf összes } \\
\text { bútorral }\end{array}$ & $\begin{array}{c}\text { „B” } \\
\text { csoportszoba } \\
\text { láthatósági } \\
\text { gráf magas } \\
\text { bútorokkal }\end{array}$ \\
\hline \multirow{3}{*}{$\begin{array}{l}\text { „B” csoportszoba } \\
\text { gyermek } \\
\text { térhasználók }\end{array}$} & Pearson korreláció - r & 1 &,- 050 &,- 082 & ,130 \\
\hline & Szign. (2-szélű) & & ,657 &, 514 & 249 \\
\hline & $\mathrm{N}$ & & 81 & 65 & 81 \\
\hline \multirow{3}{*}{$\begin{array}{l}\text { „B” csoportszoba } \\
\text { felnőtt térhasználók } \\
\text { (óvodapedagógus) }\end{array}$} & Pearson korreláció - r & & 1 & ,216 &,- 076 \\
\hline & Szign. (2-szélü) & & & ,085 &, 502 \\
\hline & $\mathrm{N}$ & & & 65 & 81 \\
\hline \multirow{3}{*}{$\begin{array}{l}\text { „B” csoportszoba } \\
\text { Láthatósági gráf } \\
\text { összes bútorral }\end{array}$} & Pearson korreláció - r & & & 1 & 020 \\
\hline & Szign. (2-szélü) & & & & 874 \\
\hline & $\mathrm{N}$ & & & & 65 \\
\hline
\end{tabular}

. p $<0,05$ szignifikancia szint (2-szélü)

8. táblázat: A „B” csoportszoba adatainak korrelációs mutatói 


\begin{tabular}{|c|c|c|c|c|c|}
\hline & & $\begin{array}{c}\text { „C" } \\
\text { csoportszoba } \\
\text { gyermek } \\
\text { térhasználók } \\
\end{array}$ & $\begin{array}{c}\text { "C” } \\
\text { csoportszoba } \\
\text { felnőtt } \\
\text { térhasználók } \\
\end{array}$ & $\begin{array}{c}\text { "C" } \\
\text { csoportszoba } \\
\text { láthatósági } \\
\text { gráf összes } \\
\text { bútorral } \\
\end{array}$ & $\begin{array}{c}\text { "C" } \\
\text { csoportszoba } \\
\text { láthatósági } \\
\text { gráf magas } \\
\text { bútorokkal } \\
\end{array}$ \\
\hline \multirow{3}{*}{$\begin{array}{l}\text { „C” csoportszoba } \\
\text { gyermek } \\
\text { térhasználók }\end{array}$} & Pearson korreláció - r & 1 &, 110 & ,064 &,- 199 \\
\hline & Szign. (2-szélü) & & ,382 & 648 & 113 \\
\hline & $\mathrm{N}$ & & 65 & 54 & 65 \\
\hline \multirow{3}{*}{$\begin{array}{l}\text { „C” csoportszoba } \\
\text { felnőtt térhasználók } \\
\text { (óvodapedagógus) }\end{array}$} & Pearson korreláció - r & & 1 &,$- 348^{* * *}$ & ,134 \\
\hline & Szign. (2-szélü) & & & ,010 & ,286 \\
\hline & $\mathrm{N}$ & & & 54 & 65 \\
\hline \multirow{3}{*}{$\begin{array}{l}\text { „C” csoportszoba } \\
\text { Láthatósági gráf } \\
\text { összes bútorral }\end{array}$} & Pearson korreláció - r & & & 1 & ,118 \\
\hline & Szign. (2-szélü) & & & & 397 \\
\hline & $\mathrm{N}$ & & & & 54 \\
\hline
\end{tabular}

9. táblázat: A „C” csoportszoba adatainak korrelációs mutatói

A csoportszobákösszesített adatainak elemzése megerősítette az „A” csoportszobában, nagyobb esetszámmal rendelkező megfigyelések eredményeit. A gyermekek térhasználata szignifikáns pozitív korrelációban áll a magas bútorokkal mért láthatósági gráfértékekkel, a felnőttek térhasználata pedig szignifikáns negatív kapcsolatban áll az összes bútorral mért láthatósági gráffal (ld. 4. táblázat).

\begin{tabular}{|c|c|c|c|c|c|}
\hline & & $\begin{array}{c}\text { gyermek } \\
\text { térhasználók }\end{array}$ & $\begin{array}{c}\text { felnőtt } \\
\text { térhasználók }\end{array}$ & $\begin{array}{c}\text { láthatósági } \\
\text { gráf összes } \\
\text { bútorral }\end{array}$ & $\begin{array}{l}\text { láthatósági } \\
\text { gráf magas } \\
\text { bútorokkal }\end{array}$ \\
\hline \multirow{3}{*}{$\begin{array}{l}\text { gyermek } \\
\text { térhasználók }\end{array}$} & Pearson korreláció - r & 1 & ,036 &,- 022 &, 130 *** \\
\hline & Szign. (2-szélü) & & 397 & ,648 & ,003 \\
\hline & $\mathrm{N}$ & & 541 & 439 & 541 \\
\hline \multirow{3}{*}{$\begin{array}{l}\text { felnőtt térhasználók } \\
\text { (óvodapedagógus) }\end{array}$} & Pearson korreláció - r & & 1 &,$- 139 * *$ & 010 \\
\hline & Szign. (2-szélü) & & & ,003 & ,813 \\
\hline & $\mathrm{N}$ & & & 439 & 541 \\
\hline \multirow{3}{*}{$\begin{array}{l}\text { Láthatósági gráf } \\
\text { összes bútorral }\end{array}$} & Pearson korreláció - r & & & 1 &, $156^{* * *}$ \\
\hline & Szign. (2-szélű) & & & & 001 \\
\hline & $\mathrm{N}$ & & & & 439 \\
\hline
\end{tabular}

**. $\mathrm{p}<0,01$ szignifikancia szint (2-szélü)

10. táblázat: A csoportszobák összesített adatainak korrelációs mutatói

\section{A két térszintaktikai mutató kapcsolata egymással}

Kutatási kérdésünk a térszintaxis mutatók kapcsolatára is irányult. Elvárhatjuk, hogy a kétféle térszintaxis-mutató együttjárjon egymással, hiszen a két láthatóságmutató között annyi különbség van, hogy amíg az egyik kiszámításakor minden bútort figyelembe vettünk, és azok mint az átlátást akadályozó tényezők jelentek meg, a másik láthatósági mutató kiszámításakor csak a gyerekek szemmagasságánál magasabb bútorok szere- peltek. A csoportszobák pedig általában - az óvodapedagógusok céljainak és a gyermekek tevékenységeinek megfelelően - úgy vannak berendezve, hogy a csoportszoba közepén kifejezetten magas, a csoportszobában való körbetekintést megnehezítő berendezési tárgyak ne jelenjenek meg.

Érdekes módon, a csoportszobákat egyenként vizsgálva, csak egy csoportszobában kaptunk szignifikáns korrelációt a kétféle térszintaxis mutató között („A” csoportszoba - ld. 1. táblázat), azonban az összes csoportszoba adatait tartalmazó elemzésben már 
Óvodás gyermekek csoportszobai térhasználatának vizsgálata a térszintaxis módszerével

magasabb szignifikancia szinten jelent meg ez az összefüggés (ld. 4. táblázat). Előfordulhat, hogy ebben az esetben az elsőfajú statisztikai hiba jelenik meg, melynek értelmében úgy fogadjuk el a hipotézisünket, hogy az nem igaz. Esetünkben erre utalhat a korrelációs mutató alacsony $(r=0.156)$ értéke is.

\section{Összegzés}

Kutatásunk eredményei azt mutatták, hogy a vizsgált óvodai csoportokban az elemzett felvételeken a pedagógusok - érdekes módon leginkább olyan térrészekben tartózkodnak a csoportszobában, melyek többé-kevésbé nehezen megközelíthetők, elérhetők. Ez a csoportszobai környezetekben nem azt jelenti, hogy a pedagógusok elbújnának a gyerekek elől, inkább azt, hogy olyan bútorokkal körülvett helyeket választanak, melyeket akár a bútorok egymáshoz való közelsége miatt nehéz megközelíteni. Ám ez nem jelenti, hogy a pedagógus egyben nem látható a gyermek számára. A játéktámogatásról jól tudjuk, hogy többször elég az óvodapedagógus támogató jelenléte, a nyugodt légkör megteremtése ahhoz, hogy a gyermekek elmélyülten tevékenykedjenek. Előfordulhat, hogy a gyermekeknek szüksége van a pedagógus aktívabb játéktámogató viselkedésére. Nem beszélve arról, hogy a pedagógus kommunikációja, hangja is a játék támogatásának „eszköze”. Ugyanakkor ez a nem várt jelenség további vizsgálatokat igényel, például a csoportlétszámmal, az óvodapedagógus csoportszobában végzendő feladataival összefüggésben.

A csoportszobában a felnőttek ezeket a térrészeket és helyszíneket a gyerekekkel együtt használják. Ahogy korábban láttuk, ha azt vetjük össze, hogy hol tartózkodik több gyerek, azokon a térrészeken, ahol felnőtt is tartózkodik, vagy azokon, ahol nem, akkor azt tapasztaltuk, hogy a gyerekek a felnőttekhez közel tartózkodnak a csoportszoba terében

A gyermekek viselkedésének vizsgálatát tekintve elmondhatjuk, hogy a gyermekek térhasználatát a térszintaktikai láthatóság segítségével becsülhetjük meg. Általánosságban elmondható, hogy a gyermekek azokat a térrészeket használják gyakran, melyek jól beláthatók. Szeretnénk azonban a "C" csoportszoba elrendezését kiemelni. A "C” csoportszobában a gyermekek leggyakrabban használt tere a kuckó volt. A három oldalról zárt, viszonylag kis alapterületű teret a gyermekek előszeretettel választották a megfigyelt mérési egységeknek több mint a felében (70 esetben, a 124 esetből) legalább egy gyerek elfoglalta a kuckót. A kuckó lélektanilag kitüntetett hellyé (Dúll, 2009) változott a csoportszobában. Vagyis ez a térrész, a kuckó, a bunker, búvóhely jelentéstartalmakat is magára vehette és így a csoport kedvelt helyévé vált. A kuckó kiemelt helyzetét erősítheti a csoport életében, hogy méretéből fakadóan egyszerre nem használhatják sokan, szemben az asztalokkal vagy az építő szőnyeggel. Láthatjuk, hogy a csoportszoba egy-egy téri adottsága, vagy akár egyéb okból kitüntetett jelentőségű helye átírhatja a térszintaktikai mutatók által előrejelzett térhasználatot.

A kuckó ilyen mértékű használatának gyakorisága alátámasztja, hogy érdemes a gyermekek számára megteremteni a csoportszobában a „kuckósítás” lehetőségét. Lehet akár állandó térrész is, mint a "C" csoportszoba esetében, de lehet olyan is, melyet a gyerekek kedvük szerint alakíthatnak ki pl. szivacs építőelemekből, összecsukható sátorból, párnákból stb.

A térszintaxis alkalmazása szempontjából - s egyben kutatásunk korlátjaként - megjegyezzük, hogy térszintaktikai mutatók vizsgálata felől közelítve az óvodai csoportszobák elemzése egy rendkívül kicsi léptékű tér nagyon speciális funkcióval és térhasználókkal, így csak megkötésekkel tudjuk az elméletet alkalmazni. A térszintaktikai mutatók és a térhasználat közötti összefüggések vizsgálata kapcsán meg kell említenünk, hogy ugyan találtunk szignifikáns kapcsolatokat, de ezek nem tekinthetőek erős együttjárásoknak (a korrelációs mutatók leggyakrabban 0,130 körüli értéket vesznek fel). Továbbá hangsúlyozzuk, hogy jelen kutatásunk feltáró jellegű. A minta mérete nem elegendően nagy az egyes csoportszobákban megjelenő egyéni különbségek, csoportszobai szabályokon túlmutató, széles körben általánosítható következtetések és összefügések megállapításához. 
Felmerül a kérdés, hogy a gyermekek és felnőttek térhasználatát a térszintaktikai mutatókkal való összevetések során kapott ellentétes irányú eredmények hátterében milyen magyarázó tényezők állhatnak. A csoportszobák kialakítása is okozhatja ezeket a különbségeket, valamint a csoportszobában megjelenő szabályok is, melyek nagymértékben az óvodapedagógustól függenek. Ezenkívül, mivel csak az „A" csoportban volt módunk több napnyi felvételt kódolni, és a „B” és „C” csoportszobából csak egy-egy felvételt elemeztünk, az utóbbiaknál előfordulhat, hogy az óvodapedagógus aznapi, aktuális tevékenysége befolyásolta a térhasználatot, míg az „A” csoportszoba esetében ez kiegyenlítettebb.

Kutatásunk rávilágít arra, hogy a csoportszoba környezetpszichológiai jellemzői milyen lényeges elemek az óvodai élet sajátosságai, „minősége” szempontjából. A fizikai környezet tulajdonságain - mint például a színek, világítás, zaj, levegő - túl a csoportszoba téri elrendezése is meghatározó. A pedagógusok - természetesen a csoportszoba adottságaihoz illeszkedően - alakítják ki a játéktereket, pedagógiai tereket, döntik el, hogy egyetlen belátható térként kezelik a csoportszobát vagy „kuckósítanak”. A tanulmányban bemutatott kutatás is rámutatott arra, hogy a tudatos tértervezés és tér(át)rendezés befolyással bír az óvodai nevelés folyamataira. Az óvodai terek tudatos tervezése, létrehozása az óvodapedagógus képzésben is megjelenik hangsúlyos témaként, kurzusokban (például a játéktér témája a játékpszichológiai-pedagógiai stúdiumokon) vagy kurzusokon kívüli programokon.

\section{Köszönetnyilvánítás}

A tanulmány írása az ELTE Felsőoktatási Intézményi Kiválósági Program (1783-3/2018/ FEKUTSRAT) keretében valósult meg az Emberi Erőforrások Minisztériuma támogatásával. Köszönettel tartozunk az ELTE TÓK hallgatóinak: Édes Reginának, Merczel Dórának, Nagy Lillának, Petrán Patríciának és Pusztaszeri Enikőnek, akik pótolhatatlan segítséget nyújtottak a kódolás folyamatában.

\section{Felhasznált irodalom}

Ata, S., Deniz, A. \& Akman, B. (2012): The physical environment factors in preschools in terms of environmental psychology: a review. Procedia-Social and Behavioral Sciences, 46., 2034-2039. https://doi.org/10.1016/j.sbspro.2012.05.424

Bafna, S. (2003): Space syntax: A briefintroduction to its logic and analytical techniques. Environment and behavior, 35. 1. sz., 17-29. https://doi.org/10.1177/0013916502238863

Behbahani, P. A., Gu, N. \& Ostwald, M. J. (2014): Comparing the properties of different space syntax techniques for analysing interiors. In Madeo, F., Schnabel, M. A. (Eds.) Across: Architectural Research through to Practice: 48th International Conference of the Architectural Science Association 2014, The Architectural Science Association \& Genova University Press, 683-694.

Böddi Zsófia, Keszei Barbara, Serfőző Mónika és Dúll Andrea (2015): A megfigyelés kutatásmódszertana: Interakciók megfigyelése integrált és inkluzív óvodai környezetben. Gyermeknevelés, 3. 2. sz., 29-50.

Böddi Zsófia (2017): Az óvodai integrált nevelés vizsgálata: Az eredményességet növelö tényezők és az óvóképzés fejlesztésének fókuszával. Doktori disszertáció. Témavezető: Hunyady Györgyné. ELTE PPK, Budapest.

Csíkos Csaba (2007): Metagkogníció - A tudásra vonatkozó tudás pedagógiája. Müszaki Könyvkiadó, Budapest.

Dúll Andrea (2007): Edukációs környezetek: oktatási-nevelési helyszínek környezetpszichológiája. In: Demetrovics Zsolt, Urbán Róbert és Kökönyei Gyöngyi (szerk.) Iskolai egészségpszichológia. L'Harmattan Kiadó, Budapest, 44-69.

Dúll Andrea (2009): A környezetpszichológia alapkérdései. Helyek, tárgyak, viselkedés. L'Harmattan, Budapest.

Dúll Andrea (2015): A bölcsőde környezetpszichológiája. In: Gyöngy Kinga (szerk.): Első lépések a müvészetek felé I., Dialóg-Campus Kiadó, Budapest-Pécs, 265-297.

Duran-Narucki, V. (2008): School building condition, school attendance, and academic achievement in New York City public schools: A mediation model. Journal of Enviromental Psychology, 28., 278-286. https://doi.org/10.1016/j.jenvp.2008.02.008

Földy Ferenc (1994, szerk.): Comenius és a magyar müvelödés. Magyar Comenius Társaság, Miskolc. 
Óvodás gyermekek csoportszobai térhasználatának vizsgálata a térszintaxis módszerével

Hegyi Ildikó (é. n.): A társadalmi környezet és az óvodás gyermek érzelmei.

URL: https://ofi.hu/tudastar/ovodai-nevelesi/ dr-hegyi-ildiko (2019. 05. 15.)

Hillier, B. (1996): Space is the machine. Cambridge University Press, Cambridge, UK.

Hillier, B. \& Hanson, J. (1984): The social logic of space. Press syndicate of the University of Cambridge, Cambridge.

Hillier, B. \& Penn, A. (1991): Visible Colleges: Structure and Randomness in the place of discovery. Science in Context, 4. 1. sz., 23-49. https://doi.org/10.1017/s0269889700000144

Kékes Szabó Marietta és Szokolszky, Ágnes (2015): Az észlelt valóság: jellegzetességek autizmusban, összevetve a tipikus fejlődéssel. Iskolakultúra, 25. 9. sz., 18-29.

Keszei Barbara, Böddi Zsófia és Dúll Andrea (2016): Lehetőségek és nehézségek a természetes megfigyelésben: Egy óvodai vizsgálat tapasztalatai. Prosperitas, 3. 2. sz., 63-86.

Kovács György és Bakosi Éva (2005): Játékpedagógiai ismeretek. Debrecen: Szerzői kiadás.

Kupritz, V. W. (2003): Accommodating Privacy to Facilitate New Ways of Working. Journal of Architecture and Planning Research, 20. 2. sz., 122.

Ljubetić, M. (2012): The Kindergarten I want to grow up in: Self-evaluation and Quality Control in Kindergartens. LAP LAMBERT Academic Publishings, Saarbrücken.
Mumcu, S., Düzenli, T. \& Özbilen, A. (2010): Prospect and refuge as the predictors of preferences for seating areas. Scientific Research and Essays, 5. 11. sz., 1223-1233.

Nash, B. C. (1981): The effects of classroom spatial organization of four-and-five-year old children's learning. British Journal of Educational Psychology, 51., 144-155.

Pálfi Sándor (é.n.): Az óvodai játék környezetkultúrája.

URL: http://ofi.hu/az-ovodai-jatekkornyezetkulturaja (2019. 04. 28.).

Peponis, J. (1985): The spatial culture of factories. Human Relations, 4., 357-390. https://doi.org/10.1177/001872678503800405

Piaget, J. \& Inhelder, B. (1999): Gyermeklélektan. Osiris, Budapest.

Polcz Alaine (1987): A rend és a rendetlenség jelensége az emberi cselekvésben. Kozmosz Könyvek, Budapest.

Stöckert Károlyné (2011): Kis játékpszichológia. Eötvös József Könyvkiadó, Budapest.

Szabó Julianna (2010): Tervezés és szabályozás a városalakításban. Tér és Társadalom, 24. 4., 29-50. https://doi.org/10.17649/tet.24.4.1789

Turner, A. (2004): Depthmap 4: a researcher's handbook.

URL: http://discovery.ucl.ac.uk/2651/1/2651. pdf (utolsó letöltés: 29.03.2019)

\section{Examining space usage of preschoolers in classrooms by using the method of space syntax}

Investigating kindergarten classrooms has an extreme importance in the field of early childhood research. Kindergarten can provide - among others - an example for effective use of socio-physical space and developing a socio-physical competence. Hence in kindergarten environments it is very important to make it easier for children to experience this efficiency. In the present study we are examining kindergarten environments and the space usage of both children and educators from an environmental psychological approach used by architects namely space syntax. Our exploratory research aims to understand the space usage of children and educators applying space syntax measurements. Natural observation was used for the research. Based on our results kindergarten educators spend more time in areas that are more difficult to access physically, but children also spend a lot of time in such areas. Space usage of children is best predicted by visibility, which means children choose areas that are visible from most vantage points within the classroom. In our opinion, the environmental psychology analysis with the approach of space syntax is useful for kindergarten educators and architects when designing, shaping classrooms.

Keywords: space syntax, natural observation, kindergarten, socio-physical space usage

Keszei Barbara, Böddi Zsófia és Dúll Andrea (2019): Óvodás gyermekek csoportszobai térhasználatának vizsgálata a térszintaxis módszerével. Gyermeknevelés, 7. 2-3. sz., 45-63. 